\title{
PEMETAAN SUHU PERMUKAAN LAUT (SPL) DAN KARAKTERISTIK PASANG SURUT DI PERAIRAN PULAU BALI, INDONESIA
}

\section{SEA SURFACE TEMPERATURE (SST) MAPPING AND THE CHARACTERISTICS OF TIDES IN THE WATERS OF BALI ISLAND, INDONESIA}

\author{
Luhur Moekti Prayogo ${ }^{1}$, Al Shida Natul ${ }^{2}$ \\ ${ }^{12}$ Magister Teknik Geomatika, Universitas Gadjah Mada, Yogyakarta, 55281, Indonesia \\ Korespondensi: luhur.moekti.prayogo@mail.ugm.ac.id
}

\begin{abstract}
ABSTRAK
Dalam bidang oseanografi, beberapa fenomena laut dapat dilihat menggunakan peta Suhu Permukaan Laut (SPL). Selain SPL, kondisi pasang surut juga penting untuk diketahui karena menggambarkan karakteristik suatu perairan. Penelitian ini bertujuan untuk mengetahui variasi SPL dan karakteristik pasang surut di perairan pulau Bali, Indonesia. Data SPL diperoleh dari National Oceanic and Atmospheric Administration (NOAA) pada tahun 2015 2017 dan data pasang surut diperoleh dari Badan Informasi Geospasial (BIG) pada bulan Juni 2017 dengan interval data satu jam. Dari hasil percobaan menggunakan metode Admiralty menunjukkan bahwa tipe pasang surut di perairan pulau Bali tergolong Campuran dengan kecendurungan Semi Diurnal dengan bilangan Formzahl sebesar $1.01(0.25<\mathrm{F} \leq 1.5)$. Kemudian parameter elevasi Highest High Water Level (HHWL) dan Lowest Low Water Level (LLWL) yang diperoleh dari perhitungan sebesar 1.0512 dan -1.0504 meter. Selanjutnya pengolahan data SPL menunjukkan pada Juni 2015 (Musim Kemarau) nilai SPL berkisar $24.05-29.11^{\circ} \mathrm{C}$ dengan rata-rata sebesar $27.73{ }^{\circ} \mathrm{C}$. Kemudian pada Desember 2016 (Musim Penghujan) nilai SPL berkisar $22.96-28.87^{\circ} \mathrm{C}$ dengan rata-rata sebesar $27.00{ }^{\circ} \mathrm{C}$. Selanjutnya pada Februari 2017 (Musim Penghujan) nilai SPL berkisar 23.36 $30.4{ }^{\circ} \mathrm{C}$ dengan rata-rata sebesar $27.20^{\circ} \mathrm{C}$. Sehingga dapat disimpulkan bahwa SPL di perairan Pulau Bali pada musim penghujan cenderung lebih rendah dibandingkan musim kemarau. Secara umum perairan utara pulau Bali cenderung memiliki suhu lebih tinggi dibandingkan dengan perairan bagian selatan.
\end{abstract}

Kata Kunci : Oseanografi, Suhu Permukaan Laut (SPL), Pasang Surut, NOAA, Bali

\section{ABSTRACT}

In the Oceanography, several marine phenomena can be seen by using a Sea Surface Temperature (SST) map. Apart from SST, tidal conditions are also important to know because they describe the characteristics of water. This study aims to determine the variation of SST and tidal characteristics in the waters of Bali island, Indonesia. SST data were obtained from National Oceanic and Atmospheric Administration (NOAA) in 2015 - 2017, and tidal data were obtained from the Geospatial Information Agency (GIA) in June 2017 with one-hour data intervals. The results of the experiment using the Admiralty method showed that the tidal type in the waters of the island of Bali is classified as a mixture with a semi-diurnal tendency with a Formzahl number of $1.01(0.25<F \leq 1.5)$. Then the elevation parameters of the Highest High Water Level (HHWL) and Lowest Low Water Level (LLWL) obtained from calculations are 1.0512 and -1.0504 meters. Furthermore, SST data processing showed that in June 2015 (dry season), the SST values ranged from $24.05-29.11^{\circ} \mathrm{C}$ with an average of $27.73^{\circ} \mathrm{C}$. Then in December 2016 (Rainy Season), the SST values ranged from $22.96-28.87^{\circ} \mathrm{C}$ with an average of $27.00^{\circ} \mathrm{C}$. Furthermore, in February 2017 (the rainy season), the SST values ranged from $23.36-30.4^{\circ} \mathrm{C}$ with an average of $27.20^{\circ} \mathrm{C}$. So it can be concluded that the SST in the waters of Bali Island in the rainy season tends to be lower than in the dry season. Generally, the northern waters of Bali tends to have a higher temperature than the southern waters.

Keywords : Oceanography, Sea Surface Temperature (SST), Tides, NOAA, Bali 


\section{PENDAHULUAN}

Selat Bali merupakan salah satu selat di Indonesia yang terletak diantara Pulau Bali dengan Jawa yang menghubungkan Samudera Hindia bagian Selatan dan Laut Bali bagian Utara (Setyohadi, 2009). Luas perairan Selat Bali relatif sempit dengan luas sekitar 960 mil (Sukojo, 2016). Fenomena iklim yang mempengaruhi dinamika perairan Selat Bali dan umumnya di perairan Indonesia yaitu Indian Ocean Dipole (IOD) dan El Nino Southen Oscillation (ENSO), akibatnya siklus musim di Selat Bali dan perairan Indonesia terjadi secara periodik, namun tidak selalu sama pada awal musim (Yamagata et al., 2002; Saputra et al., 2017). Suhu Permukaan Laut (SPL) merupakan salah satu faktor utama pergerakan siklus musim baik di daerah tropis maupun subtropis (Rini et al., 2010). Kondisi atmosfer yang berhubungan dengan SPL seperti cuaca, upwelling dan fenomena El Nino dan La Nina dapat dipelajari melalui SPL (Rini et al., 2010). Dalam ilmu oseonografi beberapa fenomena laut dapat dilihat menggunakan peta SPL secara global (Al Tanto, 2020).

Selain SPL, kondisi pasang surut juga penting untuk diketahui khususnya bagi masyarakat yang memanfaatkan laut sebagai sarana transportasi. Pasang surut adalah fenomena naik turunnya permukaan air laut pada periode tertentu dengan periode sekitar 12.4 jam atau 24.8 jam yang disebabkan oleh gaya gravitasi bulan, matahari, dan bumi (Qhomariyah, 2015). Pola pasang surut dan aktivitas pasang surut juga dipengaruhi oleh perubahan tekanan, angin dan suhu (Rinjani, 2016). SPL dipengaruhi oleh energi dari matahari, sama halnya dengan pasang surut yang juga dipengaruhi oleh matahari dan bulan (Widisanto et al., 2016). Karakteristik perairan laut suatu wilayah salah satunya juga dapat dilihat dari kondisi pasang surutnya. Penelitian terkait pernah dilakukan oleh Pranowo et al (2015) mengenai arus pasang surut di Selat Badung, Bali menggunakan komponen harmonik pasang surut. Dari hasil penelitian menunjukan pola arus di Selat Bandung di dominasi oleh arus non-harmonik ke arah tenggara.

Berdasarkan penjelasan diatas, penelitian ini bertujuan untuk mengetahui variasi SPL dan karakteristik pasang surut di perairan pulau Bali menggunakan data yang tersedia secara open source dari National Oceanic and Atmospheric Administration (NOAA) dan Badan Informasi Geospasial (BIG). Diharapkan informasi yang diperoleh dari penelitian ini dapat digunakan untuk para pengambil kebijakan khususnya pada wilayah pesisir dan laut di sekitar Pulau Bali, Indonesia. 


\section{METODE PENELITIAN}

\section{Data dan Lokasi Penelitian}

Kajian variasi SPL dan pasang surut dilakukan di sekitar perairan pulau Bali, Indonesia (Gambar 1). Lokasi ini dipilih dikarenakan ketersediaan data SPL pada Juni 2015, Desember 2016 dan Februari 2017 yang mewakili musim penghujan dan kemarau yang umumnya terjadi di wilayah Indonesia. Data SPL bersumber dari JPL ROMS (Regional Ocean Modeling System) grup, National Oceanic and Atmospheric Administration (NOAA). Kemudian data pasang surut diperoleh dari Badan Informasi Geospasial (BIG) pada bulan Juni 2017 dengan interval data satu jam. Titik pengambilan data pasang surut terletak pada $8^{\circ} 20^{\prime} 50.07^{\prime \prime} \mathrm{S}$ dan $114^{\circ} 26^{\prime} 39.37 " \mathrm{E}$ tepatnya sebelah selatan Pulau Bali.

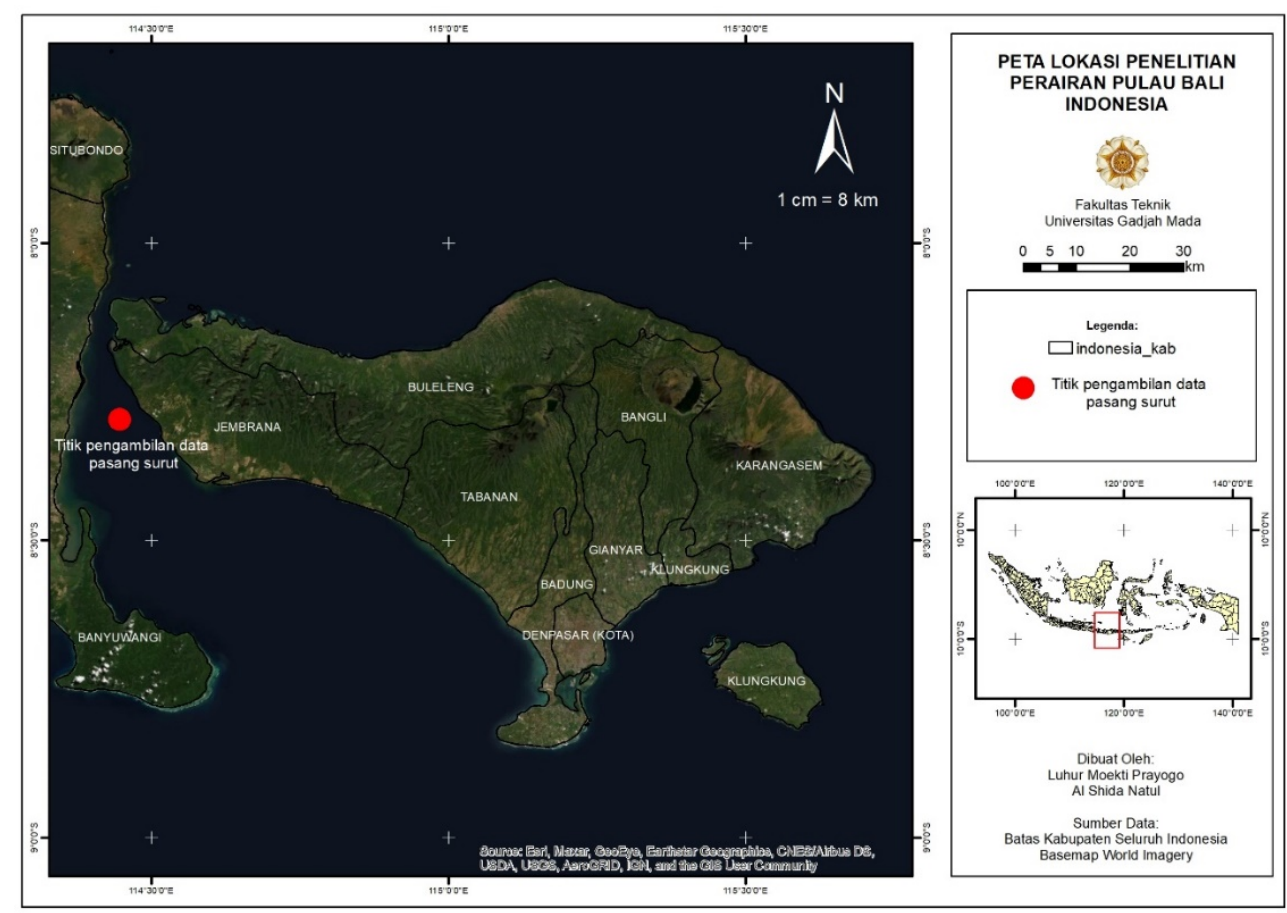

Gambar 1. Lokasi penelitian di sekitar perairan pulau Bali

\section{Metode Admiralty}

Perhitungan pasang surut pada penelitian ini menggunakan metode Admiralty. Metode ini dipilih dikarenakan dapat menghitung pasang surut dengan rentang data yang pendek yaitu 29 atau 15 piantan yang dilengkapi dengan tabel pendukung berisi nilai 
konstanta perhitungan (Fitriana et al., 2019). Kemudian untuk mengetahui karakteristik pasang surut di perairan pulau Bali yaitu dengan melihat parameter elevasi. Penelitian ini dibatasi hanya menghitung dua parameter elevasi yaitu Higher High Water Level (HHWL) dan Lower Low Water Level (LLWL). Sedangkan untuk penentuan tipe pasang surut dengan melihat bilangan Formzahl pada persamaan 1 sebagai berikut (Triatmodjo, 2009):

$$
F=\frac{(01+K 1)}{(M 2+S 2)} \ldots \ldots \ldots \ldots \ldots(1)
$$

dimana:

F: $\quad$ Bilangan Formzahl

O1: Konstanta harmonik (Deklinasi bulan mempengaruhi)

K1: Konstanta harmonik (Deklinasi bulan dan matahari mempengaruhi)

M2: Konstanta harmonik (Posisi bulan mempengaruhi)

S2: Konstanta harmonik (Posisi matahari mempengaruhi)

Dengan ketentuan nilai bilangan Formzahl sebagai berikut (Oktavia et.al, 2011; Hasibuan et.al, 2015):

Tabel 1. Ketentuan tipe pasang surut dengan bilangan Formzahl

\begin{tabular}{cc}
\hline Nilai & Tipe Pasang Surut \\
\hline $\mathrm{F} \leq 0.25$ & Semi Diurnal \\
$0.25<\mathrm{F} \leq 1.5$ & Campuran, Cenderung Semi Diurnal \\
$1.50<\mathrm{F} \leq 3.0$ & Campuran, Cenderung Diurnal \\
$\mathrm{F}>3.0$ & Diurnal \\
\hline
\end{tabular}

\section{HASIL DAN PEMBAHASAN}

\section{Karakteristik Pasang Surut}

Perhitungan pasang surut dalam penelitian ini menggunakan 8 skema dimana data yang digunakan merupakan data pasang surut pada bulan Juni 2017 dengan interval data satu jam. Pertama, dilakukan penghalusan data dengan membuat tabel kolom yang berisi tanggal dan waktu yang dimulai 00:00 hingga 23:00. Hal ini dilakukan karena data yang diperoleh dari BIG baik tanggal maupun waktu masih dalam bentuk kolom. Kedua, dilakukan pengalian dengan tabel konstanta pengali dengan tabel pengali adalah sebagai berikut (Fadilah \& Sasongko 2014) 
Tabel 2. Tabel pengali pada skema II

\begin{tabular}{|c|c|c|c|c|c|c|c|c|c|c|c|c|c|c|c|c|c|c|c|c|c|c|c|c|}
\hline & \multicolumn{24}{|c|}{ jam ke } \\
\hline & 0 & 1 & 2 & 3 & 4 & 5 & 6 & 7 & 8 & 9 & 10 & 11 & 12 & 13 & 14 & 15 & 16 & 17 & 18 & 19 & 20 & 21 & 22 & 23 \\
\hline X1 & -1 & -1 & -1 & -1 & -1 & -1 & 1 & 1 & 1 & 1 & 1 & 1 & 1 & 1 & 1 & 1 & 1 & 1 & -1 & -1 & -1 & -1 & -1 & -1 \\
\hline Y1 & -1 & -1 & -1 & -1 & -1 & -1 & -1 & -1 & -1 & -1 & -1 & -1 & 1 & 1 & 1 & 1 & 1 & 1 & 1 & 1 & 1 & 1 & 1 & 1 \\
\hline X2 & 1 & 1 & 1 & -1 & -1 & -1 & -1 & -1 & -1 & 1 & 1 & 1 & 1 & 1 & 1 & -1 & -1 & -1 & -1 & -1 & 1 & 1 & 1 & 1 \\
\hline Y2 & 1 & 1 & 1 & 1 & 1 & 1 & -1 & -1 & -1 & -1 & -1 & -1 & 1 & 1 & 1 & 1 & 1 & 1 & 1 & -1 & -1 & -1 & -1 & -1 \\
\hline X4 & 1 & 0 & -1 & -1 & 0 & 1 & 1 & 0 & -1 & -1 & 0 & 1 & 1 & 0 & -1 & -1 & 0 & 1 & 1 & 0 & -1 & -1 & 0 & 1 \\
\hline Y4 & 1 & 1 & 1 & -1 & -1 & -1 & 1 & 1 & 1 & -1 & -1 & -1 & 1 & 1 & 1 & -1 & -1 & -1 & 1 & 1 & 1 & -1 & -1 & -1 \\
\hline
\end{tabular}

Skema III diperoleh dari penjumlahan tabel pada skema II dan skema IV. Kemudian skema V dan VI melengkapi dengan tabel daftar 3a (Fadilah \& Sasongko, 2014). Selanjutya skema VII dan VIII merujuk pada Fadilah \& Sasongko (2014), yang dimulai dari penjumlahan kolom pada skema V dan VI serta perhitungan nilai PR dengan persamaan $P R=\sqrt{(P R \sin r)^{2}+(P R \cos r)^{2}}$ pada baris ke tiga. Kemudian dilanjutkan dengan menghitung dari tabel daftar 3a, node factor $\mathrm{f}$, dan perhitungan $\mathrm{V}$ dan $\mathrm{r}$ dengan persamaan $V M_{2}=-2 s+2 h$ dan $r \arctan \frac{P R \sin r}{\operatorname{Pr} \cos r^{r}}$. Selanjutya dilakukan perhitungan nilai A dengan persamaan $A=\frac{P R}{p f(1+w)}$.

Penentuan tipe pasang surut dilakukan dengan melihat nilai dari bilangan Formzahl yang dihasilkan. Dari penelitian ini menunjukkan bahwa nilai bilangan Formzahl sebesar $1.01575(0.25<\mathrm{F} \leq 1.5)$ yang berarti tipe pasang surut di perairan pulau Bali yaitu Campuran dengan kecendurungan Semi Diurnal (terjadi dua kali pasang dan dua kali surut dalam jangka waktu 12 jam 54 menit).

Selanjutnya untuk mendapatkan parameter elevasi yang akurat, setidaknya dibutuhkan waktu satu periode pasang surut (18.6 tahun). Penelitian ini dibatasi perhitungan parameter elevasi hanya menggunakan data satu bulan (Juni 2017), sehingga menghasilkan gambaran secara umum dan bukan parameter elevasi yang sebenarnya (18.6 tahun). Dalam penelitian ini, terdapat dua parameter yang dihitung yaitu HHWL dan LLWL. Air tinggi tertinggi pada saat pasang surut purnama atau bulan mati (HHWL) dari perhitungan diketahui sebesar 1.0512 meter. Kemudian parameter kedua yaitu air terendah pada saat pasang surut purnama atau bulan mati (LLWL) yang diperoleh dari perhitungan sebesar -1.0504 meter. 


\section{Karakteristik Suhu Permukaan Laut}

Pada penelitian ini, pemetaan suhu permukaan laut menggunakan data tahun 2015 hingga 2017 yang mewakili kondisi dua musim yaitu penghujan dan kemarau. Angin muson barat mengakibatkan musim penghujan yang terjadi pada bulan Oktober hingga April, sedangkan angin muson timur mengakibatkan musim kemarau yang terjadi pada April hingga Oktober. Pada penelitian ini, data tahun 2015 mewakili musim kemarau, sedangkan tahun 2016 dan 2017 mewakili kondisi wilayah Indonesia pada musim penghujan. Adapun jumlah data SPL dalam penelitian berjumlah 19.843 data yang terlampir pada tabel 3.

Tabel 3. Hasil pengolahan data SPL

\begin{tabular}{ccccc}
\hline Tahun & Bulan & Musim & Rata-rata $\left({ }^{\circ} \mathbf{C}\right)$ & $\begin{array}{c}\text { Standar } \\
\text { Deviasi }\end{array}$ \\
\hline 2015 & Juni & Kemarau & 27.73362 & 1.306574 \\
2016 & Desember & Penghujan & 27.00363 & 1.468463 \\
2017 & Februari & Penghujan & 27.20154 & 1.478452 \\
\hline
\end{tabular}

A. Suhu Permukaan Laut Tahun 2015

Pertama, pengolahan suhu permukaan laut menggunakan data tahun 2015 pada bulan Juni. Waktu tersebut mewakili kondisi musim kemarau yang umumnya terjadi di wilayah Indonesia termasuk perairan pulau Bali. Dari percobaan yang telah dilakukan, nilai SPL pada musim kemarau di perairan Bali berkisar $24.05-29.11^{\circ} \mathrm{C}$ dengan standar deviasi sebesar 1.3065. Kemudian hasil pengolahan SPL menunjukkan bahwa suhu permukaan laut rata-rata pada bulan Juni 2015 mencapai $27.73{ }^{\circ} \mathrm{C}$. Berikut merupakan peta sebaran suhu permukaan laut di perairan pulau Bali pada bulan Juni 2015: 


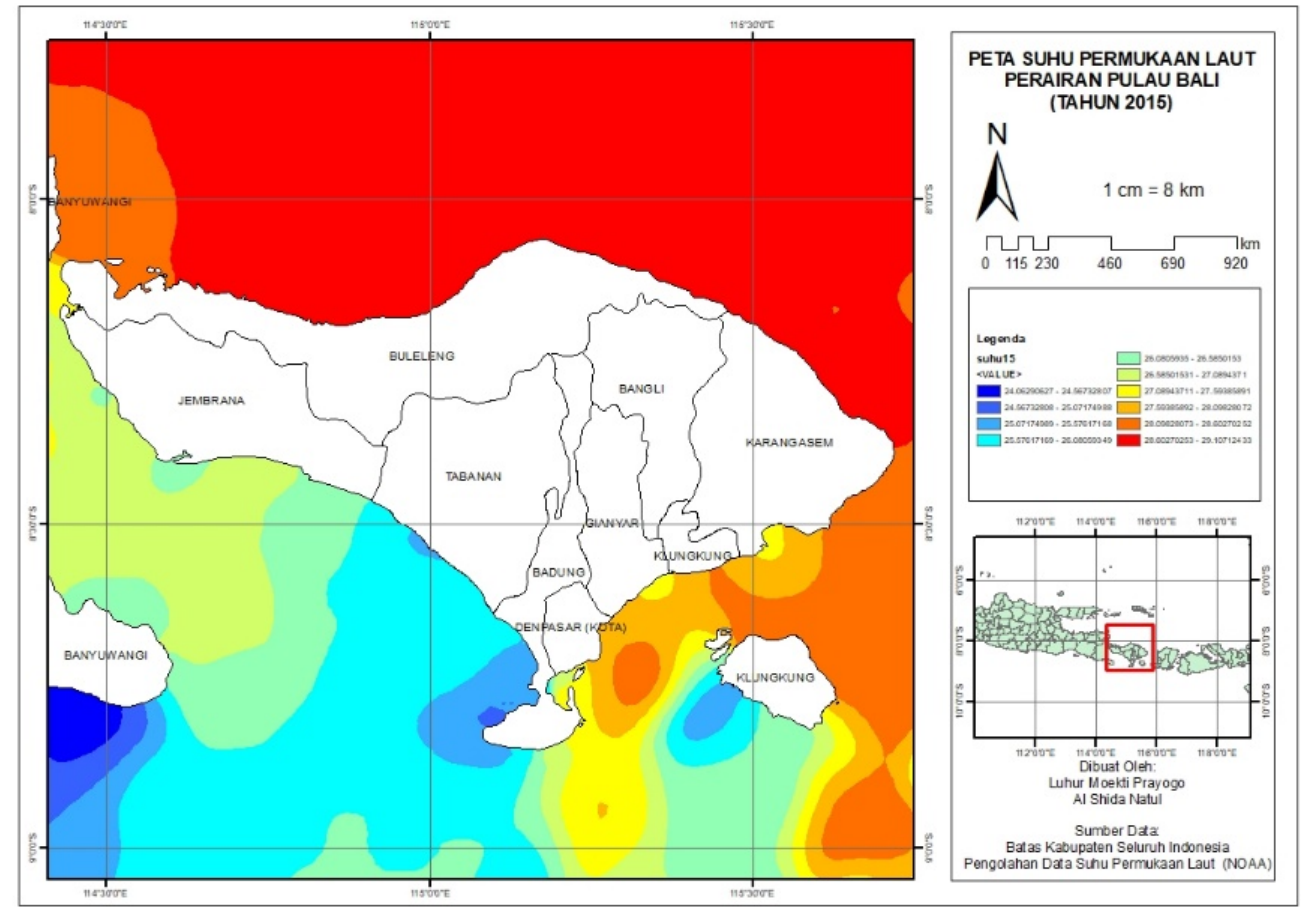

Gambar 2. Peta sebaran suhu permukaan laut pada Juni 2015

Dari peta diatas dapat diketahui bahwa sebaran SPL perairan pulau Bali bervariasi. Pada perairan bagian selatan, suhu perairan cenderung lebih rendah dibandingkan wilayah bagian utara. Bagian selatan suhu permukaan laut memiliki kisaran nilai $25-26{ }^{\circ} \mathrm{C}$. Kemudian pada perairan bagian timur, suhu berkisar $27-28{ }^{\circ} \mathrm{C}$. Kemudian suhu paling tinggi yaitu pada wilayah bagian utara dengan nilai sekitar $28-29$ ${ }^{\circ} \mathrm{C}$. Pada musim kemarau, air darat yang masuk ke wilayah laut cenderung lebih sedikit dibandingkan pada musim penghujan. Dapat diketahui bahwa laut Jawa tepatnya pada wilayah bagian utara pulau Bali cenderung memiliki suhu lebih tinggi dibandingkan dengan bagian selatan pulau.

B. Suhu Permukaan Laut Tahun 2016

Kedua, pengolahan suhu permukaan laut menggunakan data tahun 2016 pada bulan Desember. Waktu tersebut mewakili kondisi musim penghujan yang umumnya terjadi di wilayah Indonesia termasuk perairan pulau Bali. Dari percobaan yang telah dilakukan, nilai SPL pada musim penghujan di perairan Bali berkisar $22.96-28.87{ }^{\circ} \mathrm{C}$ dengan standar deviasi sebesar 1.4684. Kemudian hasil pengolahan SPL menunjukkan bahwa suhu permukaan laut rata-rata pada bulan Desember 2016 mencapai $27.00^{\circ} \mathrm{C}$. 
Berikut merupakan peta sebaran suhu permukaan laut di perairan pulau Bali pada bulan Desember 2016:

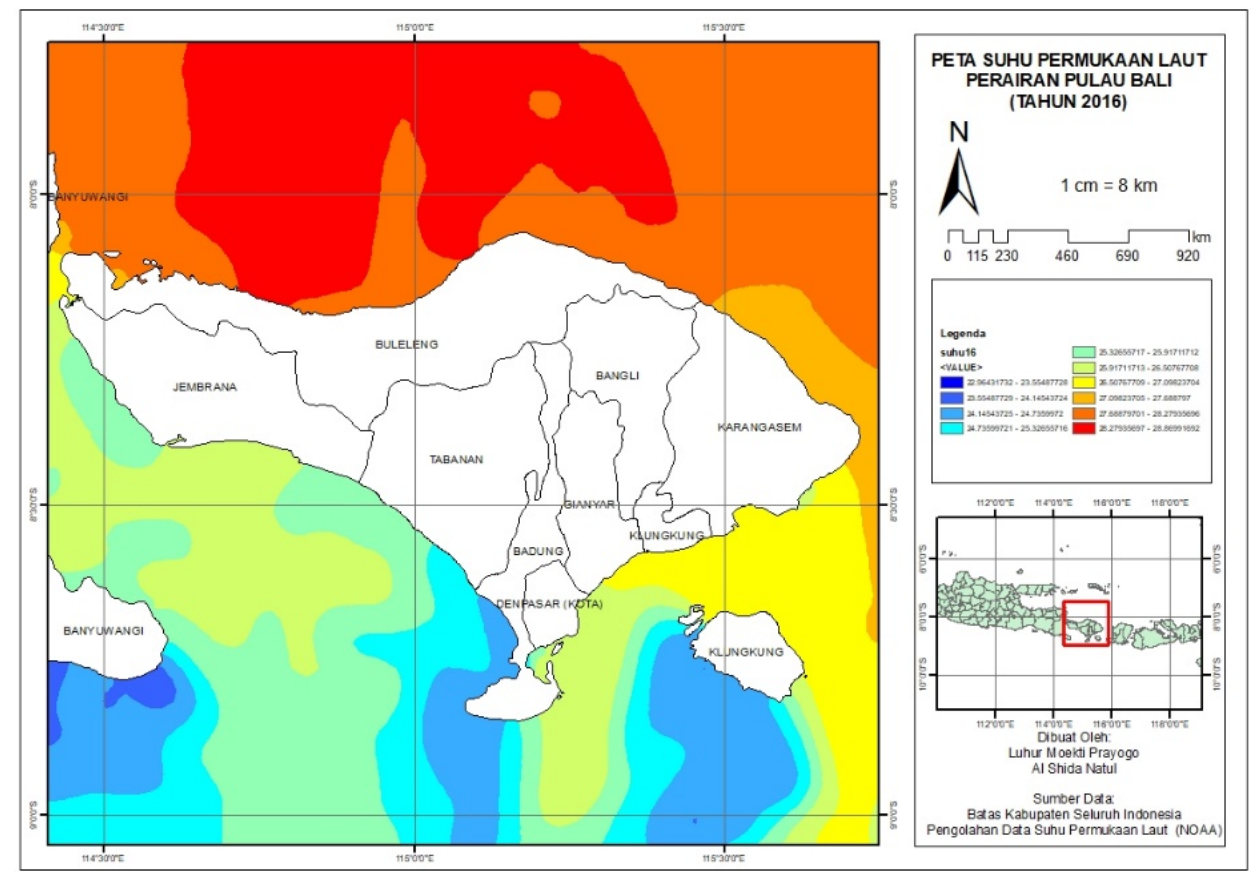

Gambar 3. Peta sebaran suhu permukaan laut pada Desember 2016

Dari peta diatas dapat diketahui bahwa sebaran SPL perairan pulau Bali bervariasi. Pada perairan bagian selatan, suhu perairan cenderung lebih rendah dibandingkan wilayah bagian utara. Bagian selatan suhu permukaan laut memiliki kisaran nilai $22-25$ ${ }^{\circ} \mathrm{C}$. Kemudian pada perairan bagian timur, suhu berkisar $26{ }^{\circ} \mathrm{C}$. Kemudian suhu paling tinggi yaitu pada wilayah bagian utara dengan nilai sekitar $27-29{ }^{\circ} \mathrm{C}$. Pada musim penghujan, air darat yang masuk ke wilayah laut cenderung lebih banyak dibandingkan pada musim kemarau. Dapat diketahui bahwa laut Jawa tepatnya pada wilayah bagian utara pulau Bali cenderung memiliki suhu lebih tinggi dibandingkan dengan bagian selatan pulau.

C. Suhu Permukaan Laut Tahun 2017

Ketiga, pengolahan suhu permukaan laut menggunakan data tahun 2017 pada bulan Februari. Waktu tersebut mewakili kondisi musim penghujan yang umumnya terjadi di wilayah Indonesia termasuk perairan pulau Bali. Dari percobaan yang telah 
dilakukan, nilai SPL pada musim penghujan di perairan Bali berkisar $23.36-30.4{ }^{\circ} \mathrm{C}$ dengan standar deviasi sebesar 1.4784. Kemudian hasil pengolahan SPL menunjukkan bahwa suhu permukaan laut rata-rata pada bulan Februari 2017 mencapai $27.20^{\circ} \mathrm{C}$. Berikut merupakan peta sebaran suhu permukaan laut di perairan pulau Bali pada bulan Februari 2017:

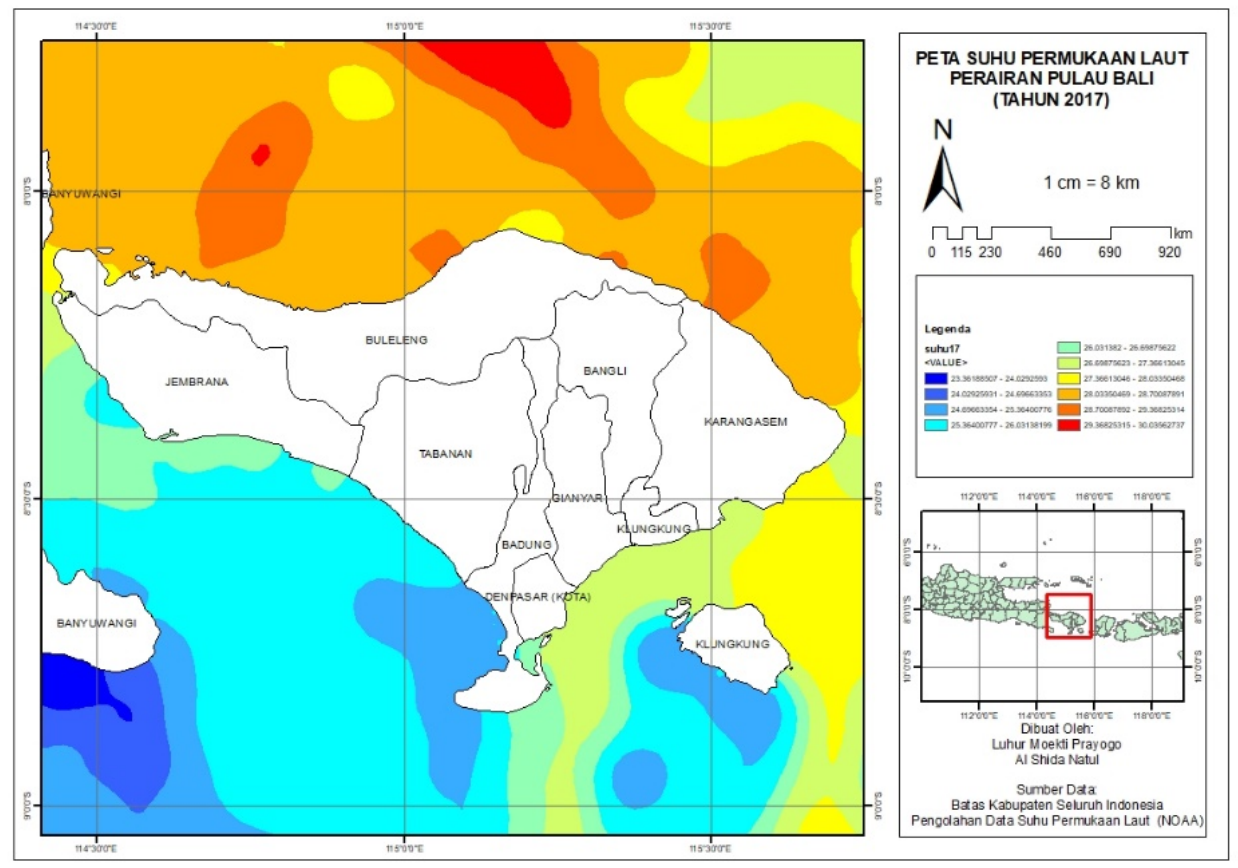

Gambar 4. Peta sebaran suhu permukaan laut Februari 2017

Dari peta diatas dapat diketahui bahwa sebaran SPL perairan pulau Bali bervariasi. Pada perairan bagian selatan, suhu perairan cenderung lebih rendah dibandingkan wilayah bagian utara. Bagian selatan suhu permukaan laut memiliki kisaran nilai $23-26^{\circ} \mathrm{C}$. Kemudian pada perairan bagian timur, suhu berkisar $>26$ hingga $28^{\circ} \mathrm{C}$. Kemudian suhu paling tinggi yaitu pada wilayah bagian utara dengan nilai sekitar $>28$ ${ }^{\circ} \mathrm{C}$. Pada musim penghujan, air darat yang masuk ke wilayah laut cenderung lebih banyak dibandingkan pada musim kemarau. Dapat diketahui bahwa laut Jawa tepatnya pada wilayah bagian utara pulau Bali cenderung memiliki suhu lebih tinggi dibandingkan dengan bagian selatan pulau.

Kemudian penelitian terkait SPL di Selat Bali pernah dilakukan oleh Sukojo (2016) menggunakan citra satelit MODIS. Dari hasil penelitian tersebut menunjukan bahwa pada bulan 
April 2012, nilai SPL berkisar $20{ }^{\circ} \mathrm{C}$ sampai $29.94{ }^{\circ} \mathrm{C}$. Kemudian pada bulan Mei 2013 meningkat antara $23.67^{\circ} \mathrm{C}$ sampai $29,97^{\circ} \mathrm{C}$. Rahadian et al (2019) juga melakukan analisis SPL pada musim barat dan musim timur di Selat Bali menggunakan citra satelit AQUA MODIS. Hasil penelitian tersebut menunjukan bahwa SPL pada Musim Barat (Penghujan) lebih tinggi dibandingkan Musim Timur (Kemarau). Penelitian selanjutnya dilakukan oleh Sari \& Wenang Anurogo (2018) menggunakan citra satelit TERRA-MODIS Level 3 untuk melihat kondisi perubahan iklim global di Batu Ampar. Hasil penelitian menunjukan kondisi oseanografi di perairan Batu Ampar tidak mengalami perubahan secara fluktuatif terhadap perubahan iklim global.

\section{KESIMPULAN DAN SARAN}

Dari percobaan yang telah dilakukan menunjukkan bahwa bilangan Formzahl yang dihasilkan dari perhitungan sebesar $1.01(0.25<\mathrm{F} \leq 1.5)$ sehingga tipe pasang surut di perairan pulau Bali tergolong Campuran dengan kecendurungan Semi Diurnal (terjadi dua kali pasang dan dua kali surut dalam jangka waktu 12 jam 54 menit). Kemudian parameter elevasi HHWL dan LLWL secara berturut-turut sebesar 1.0512 dan -1.0504 meter. Selanjutnya hasil pengolahan data SPL tahun 2015 pada bulan Juni menunjukkan nilai SPL berkisar $24.05-29.11^{\circ} \mathrm{C}$ dengan standar deviasi sebesar 1.3065 dan rata-rata mencapai $27.73{ }^{\circ} \mathrm{C}$. Selanjutnya hasil pengolahan data SPL Tahun 2016 pada bulan Desember menunjukkan nilai SPL berkisar $22.96-28.87{ }^{\circ} \mathrm{C}$ dengan standar deviasi sebesar 1.4684 dan rata-rata mencapai $27.00{ }^{\circ} \mathrm{C}$. Pada tahun 2017 pada bulan Februari, nilai SPL berkisar $23.36-30.4{ }^{\circ} \mathrm{C}$ dengan standar deviasi sebesar 1.4784 dan rata-rata mencapai $27.20^{\circ} \mathrm{C}$. Sehingga dapat disimpulkan bahwa SPL di perairan Pulau Bali pada musim penghujan cenderung lebih rendah dibandingkan musim kemarau serta diketahui bahwa laut Jawa tepatnya pada wilayah bagian utara pulau Bali cenderung memiliki suhu lebih tinggi dibandingkan dengan bagian selatan pulau. Penelitian selanjutnya diharapkan melakukan perhitungan data pasang surut menggunakan satu periode pasang surut agar menggambarkan kondisi perairan yang sebenarnya. 
UCAPAN TERIMA KASIH

Penulis mengucapkan banyak terima kasih kepada Badan Informasi Geospasial (BIG) dan National Oceanic and Atmospheric Administration (NOAA) yang telah menyediakan data sehingga dapat digunakan dalam penelitian ini.

\section{DAFTAR PUSTAKA}

Al Tanto, T. (2020). Deteksi Suhu Permukaan Laut (SPL) Menggunakan Satelit. Jurnal Kelautan: Indonesian Journal of Marine Science and Technology, 13(2), 126-142.

Fadilah, F., Suripin, S., \& Sasongko, D. P. (2014). Menentukan tipe pasang surut dan muka air rencana perairan laut Kabupaten Bengkulu Tengah menggunakan metode admiralty. Maspari Journal, 6(1), 1-12.

Fitriana, D., Oktaviani, N., \& Khasanah, I. U. (2019). Analisa Harmonik Pasang Surut Dengan Metode Admiralty Pada Stasiun Berjarak Kurang Dari $50 \mathrm{Km}$. Jurnal Meteorologi Klimatologi dan Geofisika, 6(1), 38-48. https://doi.org/10.36754/jmkg.v6i1.113.

Hasibuan RD, Surbakti H, Sitepu R. 2015. Analisis Pasang Surut dengan Menggunakan Metode Least Square dan Penentuan Periode Ulang Pasang Surut dengan Metode Gumbel di Perairan Boom Baru dan Tanjung Buyut. Maspari Journal. 7(1): 35-48.

Oktavia, R., Pariwono, J. I., \& Manurung, dan P. (2011). Variasi Muka Laut Dan Arus Geostrofik Permukaan Perairan Selat Sunda Berdasarkan Data Pasut Dan Angin Tahun 2008. Jurnal Ilmu Dan Teknologi Kelautan Tropis, 3(2), 127-152.

Pranowo, W. S., Kuswardhani, A. R. T. D., \& Purwanto, P. (2015). Karakteristik Arus Pasang Surut Di Selat Badung, Bali. Jurnal Segara, 11(2), 115-123.

Qhomariyah, L. (2015). Analisa Hubungan Antara Pasang Surut Air Laut dengan Sedimentasi yang Terbentuk (Studi Kasus: Dermaga Pelabuhan Petikemas Surabaya) (Pp. 1-3). Institut Teknologi Sepuluh Nopember.

Rahadian, L. D., Khan, A. M. A., Dewanti, L. P., \& Apriliani, I. M. (2019). Analisis Sebaran Suhu Permukaan Laut pada Musim Barat dan Musim Timur Terhadap Produksi Hasil Tangkapan Ikan Lemuru (Sardinella lemuru) Di Perairan Selat Bali. Jurnal Perikanan Kelautan, 10(2), 28-34.

Rini, D. A. S., Hidayah, Z., \& Muhsoni, F. F. (2010). Pemetaan Suhu Permukaan Laut (SPL) Menggunakan Citra satelit ASTER Di Perairan Laut Jawa Bagian Barat Madura. Jurnal Kelautan: Indonesian Journal of Marine Science and Technology, 3(2), 98-104. 
Rinjani, I. A. (2016). Pasang Surut Surabaya Selama Terjadi El-Nino. Jurnal Teknik ITS, $5(2)$, G181-G185.

Rio Demak Hasibuan, Heron Surbakti, dan R. S. (2015). Analisis Pasang Surut Dengan Menggunakan Metode Least Square Dan Penentuan Periode Ulang Pasang Surut Dengan Metode Gumbel Di Perairan Boom Baru Dan Tanjung Buyut. Maspari Journal, 7(1), 35-48.

Saputra, C., Arthana, I. W., \& Hendrawan, I. G. (2017). The Vulnerability Study Of Lemuru (Sardinella Lemuru) Fish Resources Sustainability In Bali Strait In Corellation With Enso And Iod. Ecotrophic: Jurnal Ilmu Lingkungan (Journal of Environmental Science), 11(2), 140-147.

Sari, R., \& Wenang Anurogo, M. Z. L. (2018). Pemetaan Sebaran Suhu Penggunaan Lahan Menggunakan Citra Landsat 8 Di Pulau Batam. Jurnal Integrasi, 10(1), 3239. https://doi.org/ISSN: 25489828.

Setyohadi, D. (2009). Studi potensi dan dinamika stok ikan lemuru (Sardinella lemuru) di Selat Bali serta alternatif penangkapannya. Jurnal Perikanan Universitas Gadjah Mada, 11(1), 78-86.

Sukojo, B. M. (2016). Analisis suhu permukaan laut untuk penentuan daerah potensi ikan menggunakan citra satelit modis level $1 \mathrm{~b}$ (studi kasus: Selat Bali). Jurnal Teknik ITS, 5(2), A846-A849.

Triatmodjo, B. (2009). Perencanaan Pelabuhan. Beta Offset. 490 hal.

Widisanto, H., Pranowo, W. S., \& Setiadi, H. (2016). Studi Konstanta Harmonik Pasang Surut Terhadap Data Suhu Permukaan Laut di Perairan Pulau Pari. Jurnal Chart Datum, 2(2), 139-151.

Yamagata, T., Behera, S. K., Rao, S. A., Guan, Z., Ashok, K., \& Saji, H. N. (2002). The Indian Ocean dipole: A physical entity. CLIVAR Exchanges, 24(7), 2. 